\title{
Pergeseran Fungsi dan Bentuk Ronggeng di Jawa Barat
}

\author{
Anis Sujana \\ Sekolah Tinggi Seni Indonesia (STSI) Bandung \\ Jalan Buah Batu No. 212 Bandung
}

\begin{abstract}
Generally the term ronggeng is used to call female performer, 'being paid', and is usually imaged badly. However, in the other side, ronggeng also performs in fecundity rituals and becomes the source of blessing. It can be seen here that ronggeng has double function and role.

This writing is aimed at seeking for functions and types of ronggeng arts in western Java. The result shows that in many cases socio-culturally ronggeng is on profane functions, that is, as entertainers. Related to their performance techniques, there are several functions: 1) as audience partners in social intercourse dance; 2) as actors in some traditional theatres; 3) as dance performers and 'single' singer as well as jester; 3) as song performers (sinden) in wooden puppet; 5) as performers in magic performance; and 6) as performers in helaran performance. On the other side, ronggeng also has sacred function, that is as the rites performers, especially on fecundity ones; in this case, ronggeng has ambiguous functions, that is as rites performers in one side, and on the other side as entertainers.
\end{abstract}

Keywords: ronggeng, function and type, entertainment, rites.

\section{Pendahuluan}

Kata ronggeng pernah (dan bahkan masih) dikenal di nusantara khususnya wilayah-wilayah etnik yang memiliki tradisi ronggeng. Di wilayah-wilayah tersebut kata ronggeng diartikan sebagai perempuan pelaku pertunjukan yang 'dibayar'. Dalam arti demikian, ronggeng memiliki stereotipnya antara lain: ledhek, tandhak, waranggono, Lengger, gandrung, (Jawa Tengah dan Jawa Timur), joged dan gandrung (Bali dan Lombok), sindur (Madura), pajo- geq (Bugis, Makasar), makyong (Sumatera), cokek (pinggiran Jakarta), doger dan dombret (Jawa Barat). Arti denotatif demikian kemudian melebar dan menemukan arti konotatifnya yaitu perempuan 'murahan'. Di lain fihak beberapa fakta menunjukkan bahwa sebagai pelaku pertunjukan ronggeng-ronggeng tersebut kerap tampil mengiringi upacara, khususnya upacara kesuburan yang oleh sebab itu mereka dihormati, dimuliakan, dan ditanggapi se- 
bagai sumber berkah.

Jawa Barat dikenal kaya dengan jenisjenis ronggeng, baik dalam pengertian 'sosok perempuan pelaku hiburan' maupun dalam pengertian kesenian (seni ronggeng). Seni-seni ronggeng tersebut sebagian berciri lokal, artinya hanya terdapat di wewengkon tertentu saja, dan sebagian berciri regional artinya terdapat di seluruh peloksok Jawa Barat. Mengingat keanekaragaman sebutan dan bentuk pertunjukannya diduga keras bahwa telah terjadi pergeseran fungsi dan bentuk ronggeng. Berdasarkan pada dugaan itu, maka permasalahan penelitian ini adalah pergeseran fungsi dan bentuk ronggeng di Jawa Barat.

Metode yang digunakan adalah metode observasi; data dikumpulkan lewat studi pustaka, wawancara, dan pengamatan langsung ke lapangan. Pengamatan ditujukan kepada berbagai kesenian ronggeng dan/atau bentuk-bentuk stereotipnya.

\section{Bermakna Perempuan dari sudut Etimo- logis}

Tentang kata ronggeng, Kusumah (1981/1982:5-9) mengaitkannya dengan kata renggana (Bahasa Sanskrit) yang berarti perempuan pujaan atau perempuan penghibur para tamu di istana-istana kerajaan. Di fihak lain, Suharto (1999: 66-67) mengaitkan kata ronggeng tersebut dengan kata rengganis (akronim dari rengga, hiasan, dan manis); dan yang dimaksud adalah Dewi Kembang Samboja, yaitu tokoh putri yang menyamar menjadi ronggeng sekaligus menjadi awal mula munculnya kesenian Ronggeng Gunung di Ciamis selatan. Kedua sumber itu pada dasarnya sama yakni memaknai kata ronggeng sebagai perem- puan, dan ini akan serupa dengan apa yang akan diuraikan selanjutnya. Namun demikian masih perlu penelaahan lebih lanjut, dalam arti kedua sumber itu tidak menyajikan analisis bagaimana kata-kata rengga dan rengganis bergeser secara linguistik sehingga menjadi kata ronggeng.

Dalam kaitan pergeseran kata ini patut diduga bahwa kata ronggeng berasal dari kata rong, kosa kata Jawa Kuna yang diartikan sebagai 'lubang' (Mardiwarsito, 1990:479). Pemberian arti 'lubang' ini dapat dibandingkan dengan kata-kata corong, gorong (dalam gorong-gorong), dan rongga yang juga menunjuk kepada sesuatu yang berlubang. Di sisi lain dimungkinkan juga bahwa kata rong sebagai bentuk ujaran dari rwang, yang dalam Bahasa Sunda: ruang, ngaruang menunjuk kepada pengertian menimbun atau memasukkan sesuatu ke dalam lubang. Di fihak lain kata rong, setidak-tidaknya di Banyumas, memiliki pengertian 'sarang' (Wulandari, 2000:47) yang tampaknya tidak berbeda dari 'lubang' dan 'ruang'. Adapun perubahannya menjadi ronggeng setelah mendapat preposisi ing yang dalam Bahasa Jawa Kuna selain dapat diartikan di, pada, oleh, dengan, kepada, dalam, tentang, menunjuk kepada subjek/objek, juga sebagai kata yang tidak perlu diterjemahkan (Mardiwarsito, 1990:238-239). Dengan begitu kata ronggeng dibangun dari katakata rong (rongga) dan ing yang kemudian dilafalkan menjadi ronggeng, seperti halnya kata-kata jaya dan ing menjadi jayeng (umpamanya dalam jayenglaga atau jayengrana yang artinya menang dalam perang). Sekarang tampak baik 'lubang', 'ruang', maupun 'sarang' sebagai terjemahan dari kata rong menunjuk kepada makna yang sama yaitu perempuan (dalam konteks seks, kelamin) seperti juga gelap, tertutup, 
lembab-basah, menyimpan, bulat, segi tiga, berongga, wadah, yang semuanya mengarah kepada makna perempuan (Sumardjo, 2004: 6). Dari tanggapan demikian maka dapat ditegaskan bahwa arti kata ronggeng itu adalah perempuan.

\section{Penari dan Penghidang Lagu}

Pada perkembangan lebih lanjut, kata ronggeng itu mengalami reduksi yaitu dibatasi pada perempuan dengan peran dan kedudukan tertentu dalam masyarakat, atau lebih jelas lagi sebagai pelaku seni pertunjukan. Data visual yang dianggap tua adalah pelukisan pada relief Candi Borobudur, dan juga pada salah sebuah patung pada plato Dieng yang menunjuk kepada gejala ronggeng yang bagaimanapun melukiskan sosok perempuan yang sedang menari (Sutarno, 2002: 7-8). Kemudian, dari cerita rakyat yang mengisahkan asal-usul ronggeng terindikasi bahwa ronggeng menunjuk kepada perempuan penari sekaligus penghidang lagu. Inti cerita itu adalah tiga lelaki (pemahat, penjahit, dan panday mas) masing-masing merasa berhak atas patung perempuan yang kini telah menjelma menjadi perempuan cantik. Berkaitan dengan cerita itu Holt (1967:113) mengatakan:

\section{But the Wali ordered all three to accompany the woman, who was to dance and sing, wander- ing through the country. The wood carver was to play the rebab (one-string violin), the tailor was to beat the drum, and the goldsmith was to play the gong, kecrek, and ketuk (all percussion instruments). They obeyed and the four wan- dered out and on to Majapahit. And thus it was shown that the dance girl does not belong to one but too many.}

Di Jawa Barat, gejala ronggeng sebagai pelaku pertunjukan tersebut digambarkan dalam Carita Pantun (Pantun Bogor, dalam cerita Sri Langlang Bumi), dengan disebut-sebutnya Ronggeng Tujuh Kalasirna yang menunjuk kepada tujuh puteri bidadari yang diutus turun ke marcapada dengan menyamar menjadi ronggeng, serta mengadakan pertunjukan keliling (Nalan, 1994:79-80). Keterangan lainnya adalah pada Kamus Umum Basa Sunda (1994:28) yang menyatakan bahwa ronggeng adalah: awewe nu sok ngigel bari ngawih ngabarengan gamelan [perempuan yang biasa menari sambil menyanyi menyertai gamelan]; selain itu juga dalam Ensiklopedi Sunda (2000:551) yang menyatakan: pada masa sebelum perang, semua perempuan yang menyanyi atau menari di depan umum disebut ronggeng. Kemudian dengan mengutip salah-satu bait dalam Kidung Sunda, Zoetmulder (1982:1724) memaknai kata ronggeng sebagai penari perempuan yang dibayar.

Dari sumber-sumber di atas kiranya dapat ditarik kesimpulan bahwa kata ronggeng menunjuk kepada sosok perempuan penari yang tampil kaitannya sebagai partner laki-laki dalam arena tari pergaulan. Selebihnya mereka dibayar untuk jasa-jasanya itu. Pada gilirannya kehadiran ronggeng pada suatu bentuk pertunjukan tertentu telah merefleksikan penamaan pertunjukannya yaitu seni ronggeng.

\section{Wahana Prostitusi}

Bersangkut-paut dengan partner lelaki dalam arena tari pergaulan dan dibayar, kerap terjadi ekses negatif yaitu bahwa ronggeng memberikan juga 'pelayanan khusus' terhadap siapapun yang mempunyai hasrat seksual terhadap mereka. Dalam budaya Jawa, dalam Serat Cabolang dan Serat Centini diperoleh keterangan 
tentang pelaku ronggeng yang selain menari juga melakukan praktek prostitusi. Edi Sedyawati (2000:68) mengatakan:

Mereka ini dibayar untuk jasanya menemani tuan-tuan menari dalam pesta tari...maupun juga untuk kesediaannya dibawa pergi untuk bercumbu rayu...hubungan gambyongan dengan prostitusi pada waktu itu rupanya demikian eratnya...

Kemudian, di wilayah Priangan, beberapa peneliti asing memberikan keterangan tentang seni ronggeng jalanan yang menyatakan ronggeng sinonim dengan pelacur. Dalam kaitan ini Raffles (1837: 342) melaporkan: "Their conduct is generally so incorrect, as to render the title of rong'geng and prostitute synonymous..."

Kurang dari satu abad fenomena yang sama dilaporkan oleh peneliti Belanda. Hardouin (1855:211) tentang temuannya di Betawi dengan menyatakan: "Deze rongging's, op de nevensgevoegde platen afgebeeld, zijn doorgaans ontuchtige vrouwen uit den laagsten stand, welke eenen dans uitvoeren, tandakh genaamd,..."1 Sementara jauh sebelumnya (1779) telah dilaporkan juga oleh Lombard (1996: 250) dalam temuannya di perkebunan tebu milik orang Cina dengan mengatakan: “...kesempatan berpesta pora di perkebunan, dengan pertunjukan wayang (waijang spel) dan pertunjukan tari atau ronggeng."

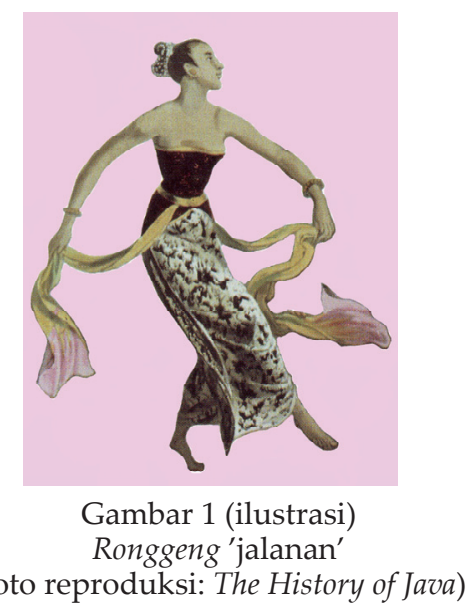

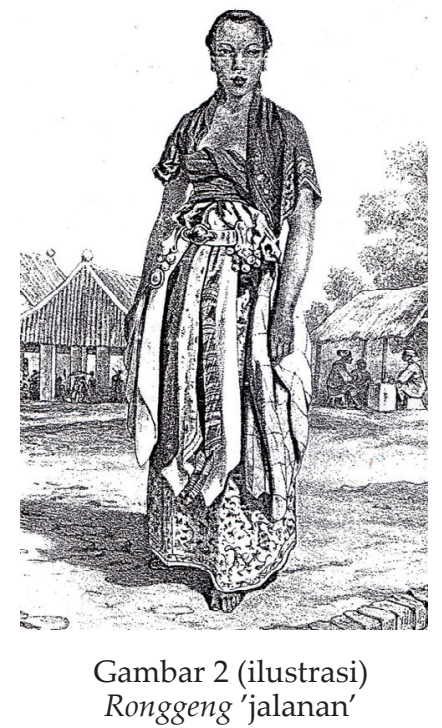

(foto reproduksi: Java: Neelen Uit Het Leven, Karakterschetsen en Kleederdragten van Java's Bewoners).

Keadaan yang sama di temukan juga di Bali, terutama pada masa kejayaan rajaraja di mana dikenal beberapa Seni Joged, di antaranya Joged Tongkohan, Joged Bumbung, dan Joged Pingitan. Dalam kaitan ini Van Eck (Bandem, 2000: 54) melaporkan:

Setelah tarian selesai, penari memisahkan
dirinya dan duduk di antara para penon-
ton, penari wanita mengikutinya untuk
mendapatkan bayarannya.. dan untuk
jumlah yang sedikit itu dia berkewajiban
untuk duduk di pangkuan penari dan
kawan-kawannya serta menerima elusan-
elusan mereka.

Lebih lanjut Van Eck (Bandem, 2000: 54) mengemukakan:

\begin{abstract}
Sangat menggelikan ketika kami melihat wanita itu ditarik ke sana kemari di tengah malam gulita dan biasanya wanita itu dicium bertubi-tubi dengan pelukan yang mesra oleh muda dan tua tanpa diberi kesempatan untuk menolaknya.
\end{abstract}

Kemudian pada masa Gubernur Jenderal Van den Bosch (1830-1833) dan Baud (1833-1836) di mana Belanda memberlakukan 'Tanam Paksa' (Cultuurstelsel) yang dijalankan untuk menutup kas negara yang kosong akibat Perang Dipenogoro (1825- 
1830). Pada 'Tanam Paksa' ini pemerintah Belanda berupaya bagaimana agar kulikuli itu betah di wilayah onderneming itu. Cara yang dilakukan antara lain dengan memberikan hiburan-hiburan ronggeng: selain itu perjudian termasuk yang dilegalkan. Dalam kaitan ini diberitakan selanjutnya bahwa di daerah perkebunan Karet di Pasaman Sumatera Barat terdapat ronggeng dan tandakh. Demikian juga di Kalimantan Selatan khususnya Kabupaten Hulu Sungai Selatan (Kleden, 2000:49). Dari sebuah gambar terlihat beberapa ronggeng yang tengah berpose dengan seting bangunan di wilayah onderneming di Deli. Menurut Suyono (2005:120) ronggengronggeng tersebut dikirim bersama-sama dengan tenaga-tenaga kuli termasuk juga para centeng dan termasuk juga peralatan keseniannya.

Gambaran lainnya adalah di Banyumas, sebagaimana tergambar pada Ronggeng Dukuh Paruk. ${ }^{2}$ Dalam tradisi masyarakat Dukuh Paruk, selain berpentas dan menari, ronggeng juga bertugas melayani laki-laki yang memilki hasrat seksual kepada mereka. Laki-laki yang mendapatkan kesempatan tidur dengan seorang ronggeng menunjukkan kekuatan, baik dalam hal seksual maupun materi sehingga ia mengangkat citra dirinya di hadapan masyarakat sekitarnya. Gambaran tentang Ronggeng Srintil yang menjual keperawanannya melalui sebuah ritus yang disebut bukak klambu, secara implisit menegaskan bagaimana ronggeng identik dengan menjual diri.

Dari beberapa gambaran tersebut tampak bahwa ronggeng dipertalikan dengan perbuatan a-susila. Tak heran pada gilirannya ronggeng memiliki citra buruk, dianggap paradoks. Sebagian dari mereka terpaksa dikucilkan dari kehidupan yang tertib, atau dengan atas kesadaran sendiri membuat jarak dan menjauhkan diri dari pergaulan sehari-hari.

\section{Antara 'Dunia Nyata' dan 'Dunia Mak- na'}

Jauh sebelum indianisasi, 'pembaratan', dan juga pengaruh Islam, animisme merupakan salah satu agama asli Indonesia. Agama ini difahami sebagai bentuk kepercayaan terhadap roh yang dapat merasuk ke dalam tubuh atau benda, dan sementara menjadikannya sebagai tempat tinggal (dalam keadaan demikian dia dapat dimintai nasihatnya, pengetahuan apa yang akan terjadi, tersembunyi dan lain-lain). Untuk dapat merasuk ke dalam tubuh manusia roh ini sewaktu-waktu dapat diundang dengan sengaja dan dapat merasuk dengan sendirinya. Roh yang sengaja 'diundang' perlu menjadikan seseorang sebagai mediator, atau bisa juga melalui bantuan orang lain, sedang untuk roh yang tidak disengaja 'diundang' akan datang dengan sendirinya manakala tubuh dan jiwa seseorang dalam keadaan labil.

'Mengundang' roh seringkali dilakukan lewat ritus. Dalam laku ini dibutuhkan kekuatan lain yaitu 'mana' (cakti), yang untuk memperolehnya diperlukan suatu tanda eksternal yaitu ritual-magis. Laku ritual magis seringkali merupakan sumber penting dari inspirasi artistik yang tidak lepas dari lambang-lambang yang dipakainya: puisi, bunyi-bunyian, gerak, hingga benda-benda yang dapat diraba dan dirasakan seperti sesajian (Brandon, 1967:10). Dalam kata lain ia merupakan kombinasi dari beberpa artefak dan berbagai tindakan.

Gejala ronggeng sangat bertalian dengan laku-laku ritus tersebut. Hal ini 
ditegaskan oleh Alkema yang menyatakan bahwa ronggeng itu adalah shaman dalam shamanisme, Menurut Wilken selain ronggeng penari shaman dalam fungsinya seperti itu tersebar di nusantara di antaranya sibaso marende-rende (Batak), walian (Alfur dan Minahasa), sangiang (Bali), olo ngaju, balian, olo maajuan, wadian (Dayak), pajoge (Makasar dan Bugis), dan taledhek (Jawa) (Surjaatmadja, 1980:5). Menurut Ben Suharto (1999:15) bilamana ronggeng melakukan gerak-gerak yang cenderung erotis, sendiri atau berpasangan dengan lelaki, sesungguhnya itu adalah perbuatan magi yaitu untuk mempengaruhi tumbuhnya tanaman. ${ }^{3}$

Andai seni ronggeng adalah konsep seni ritus maka salah-satu perwujudannya ditemukan pada Seblang. Seblang yang masih hidup di tengah-tengah suku Osing (Banyuwangi) dipentaskan berkaitan dengan 'tolak-bala', 'bersih-desa', dan kesuburan. Pelakunya seorang perempuan yang 'menari' dalam keadaan tidak sadar dan diiringi gamelan. Dalam menari itu gerakannya mengalir begitu saja, tumpuan kaki pada telapak kaki depan serta adanya gerakan pinggul. Dalam fungsi dan bentuk seperti itu Seblang dipentaskan pada arena terbuka, membentuk sebuah lingkaran. Di bagian belakang tersimpan beberapa perlengkapan sesajen. Tempatnya ditinggikan serta dipayungi. Kemenyan dibakar untuk asapnya dihirup pemain Seblang hingga tak sadarkan diri (Mudiasih, 2002:69).

Perkembangan lebih lanjut terjadi pergeseran fungsi ronggeng yaitu dari sakral ke profan. Namun demikian beberapa gejala masih mampu memperlihatkan benang merah aspek sakralnya. Di Jawa (Pati, Blora, Jepara, Grobogan, Sragen, Wonogiri, Tuban, dan sebagainya), Tayub merupakan hiburan terpopuler dan biasa ditampilkan pada bersih desa dan pesta perkawinan. Pada upacara 'bersih-desa' yang harus menari pertama kali dengan ronggeng (ledhek) itu adalah tetua atau kepala desa. Babak ini dikenal dengan bedhah-bumi yang melambangkan lelaki membelah rahim perempuan. Hal ini dipercaya akan dapat menyuburkan tanah sehingga panen melimpah. Kemudian pada pesta perkawinan, mempelai pria diharuskan menari bersama ledhek; tiada lain dimaksudkan untuk memperoleh 'kesuburan' (Suharto, 1999:109-111). Kemudian di Gunung Kidul, juga pada Tayub, dikabarkan seorang ibu menciumkan anak-balitanya ke salah seorang ronggeng (ledhek) yang tengah berdandan sambil berucap agar anak itu tetap sehat, tidak rewel, tidak nakal, cepat dewasa serta pandai sekolah pula nantinya (Suharto, 1999:92). Selanjutnya masih seputar Tayub, di Purworejo, bahkan ronggeng dianggap sebagai dukun yang mampu mengobati yang sakit, yang dalam kaitan ini pupur (bedak) dan bahkan air ludah (liu/Jw.) ronggeng dipercaya akan menyembuhkan seseorang dari sakit, atau sekurang-kurangnya dapat menyembuhkan sawan dan kesurupan (Haryono, 2002:39-40).

Sementara itu di Banyuwangi, Gandrung melibatkan penari gandrung dan pemaju, serta melibatkan orkestra gamelan. Gerakannya cenderung erotik, terutama tertumpu pada tungkai terbuka serta penggunaan lengkungan putaran, serta pergetaran tangan. Jika hadir pada perayaan perkawinan maka mempelai pria yang mendapat kesempatan pertama menari bersama gandrung. Yang menarik adalah bahwa dalam satu babak lagu seorang penari gandrung ditemani empat orang pemaju, dengan bloking: penari gandrung berada di tengah-tengah sedang keempat 
pemaju berada di empat sudutnya. Namun di sini ada aturan bahwa pemaju dilarang bersentuhan dengan gandrung, bilama ada gelagat ke sana maka tukang kluncing akan melakukan kode-kode tertentu umpamanya lewat gerak yang jenaka. Gandrung di tengah boleh dilambangkan sebagai axismundi, poros bumi. Aturan dilarang bersentuhan adalah norma yang diberlakukan kemudian. Di Lombok, penari Gandrung serupa itu akan mendapat imbalan uang atau hasil bumi dari masyarakat manakala mereka telah menyelesaikan tugasnya (Larasati, 1996: 17). Di fihak lain, dalam Ronggeng Dukuh Paruk, sekalipun tidak secara langsung memainkan peran penting dalam festival desa, namun ronggeng dianggap sebagai 'bukan sembarang manusia'; penulis novel itu memberi gambaran bahwa tidak setiap perempuan dapat menjadi ronggeng kecuali perempuan itu mendapat titisan indang (Tohari, 1970).

Dari sekilas uraian di atas dapat dinyatakan bahwa ronggeng menempati kedudukan sakral dalam masyarakat, dianggap istimewa, penuh berkah. Tak terkecuali pandangan kaum sufi di Cirebon; pada Babad Cirebon dikemukakan adanya tabir-tabir pemisah antara manusia dengan tuhannya. Dalam kaitan ini ronggeng merupakan gambaran dari ma'rifat, karena antara pemain dan yang dimainkan masih itu juga, tanpa adanya unsur yang menutup apapun. Maka itu jalan pemecahan ada pada ke-Tuhan-an Yang Maha Agung, tidak lagu berwujud dua, tetapi sudah bersatu segala-galanya bagaikan manusia penjelmaan Tuhan (D.A. Rinkes, dalam Surjaatmadja, 1980: 31-32).

\section{Lelaki yang Memerankan Perempuan}

Di Banyumas dan Purbalingga (Jawa Tengah) terdapat kesenian Lengger yang menurut Supriyadi $(2003,39)$ baru sekitar tahun 1918 diperankan oleh perempuan. Selain itu di Jombang (Jawa Timur) pernah muncul Wedokan yang penarinya lakilaki yang memerankan perempuan, sama dengan kesenian Gandrung di Banyuwangi, Bali, dan Lombok. Menurut sebuah sumber, pada suatu masa tertentu di Banyuwangi (Jawa Timur) muncul sebutan gandrung lanang, yang setelah lama mengalami stagnasi kemudian muncul penari Gandrung yang diperankan oleh seorang perempuan bernama Semi (Supriyanto, 1994:76). Sumber lain menyebutkan bahwa penari Gandrung di Bali diperankan oleh laki-laki dan menjadi lambang cinta kasih atau kerinduan. Dalam kaitan ini I Made Bandem (2000:62) menyatakan sebagai perlambang kesuburan dan dapat mengakibatkan cinta birahi.

Di Bali dan Jawa terdapat tari-tari Gandrung yang dilangsungkan pada upacaraupacara perkawinan. Biasanya yang menari adalah anak laki-laki yang berpakaian seperti gadis dan para tetamu ditunjuk beberapa orang untuk menyertai dalam permainan itu.

Sementara itu di Lombok dikenal tokoh penari Gandrung laki-laki dari Dusun Tereng bernama Inaq Bilin yang menurut Larasati (1996:19) menjadi pewaris dari tokoh Gandrung terdahulu yang juga lakilaki.

\section{Ronggeng di Jawa Barat}

Seni-seni ronggeng di Jawa Barat sebagian mencantumkan kata ronggeng dalam sebutannya (Ronggeng Gunung, Ronggeng Amen, Ronggeng Ketuk atau Ketuk Tilu, Ronggeng Kedempling, Ronggeng Kocapi, Ronggeng Wayang, Ronggeng Buyung dan Ronggeng Bugis), dan sebagian lagi menggunakan kata lain (Tayub, Longser, Uyeg, Banjet, Bangreng, Doger, Dombret, dan Bajidoran). 


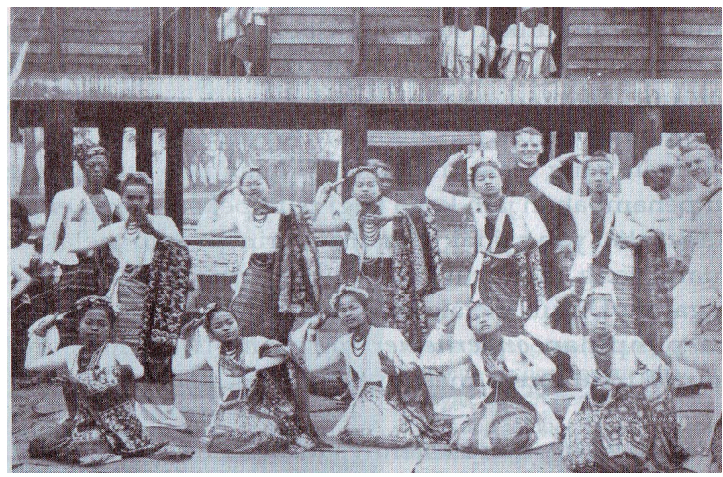

Gambar 3 (foto)

Ronggeng-ronggeng yang dikirim ke wilayah-wilayah perkebunan di Deli (reproduksi: Seks Dan Kekerasan Pada Zaman Kolonial, Penelusuran Kepustakaan Sejarah)

Kaitan stereotip ronggeng dalam pengertian pekerja seks komersial dan atau dieksploitasi untuk kepentingan penguasa dan kelompok tertentu, di Bandung, hingga pertengahan abad ke-20 ronggengronggeng itu di bawah koordinasi centeng (Yohana, t.t.:33). Kemudian di Sumedang, tepatnya di Kecamatan Buahdua, dilaporkan muncul tiga grup Ketuk Tilu yang biasa mentas di tempat tinggal para pimpinannya yang lebih lanjut diketahui sebagai rumah bordeel (Aki Kaih, wawancara). ${ }^{4}$ Di lain fihak, di pesisir pantai utara, termasuk ke dalam wilayah Kabupaten Subang dan Indramayu dikenal kesenian Dombret. Sebagai stereotipe ronggeng, kesenian Doger ini merupakan wahana transaksi seksual yang pelaku umumnya adalah para nelayan.

Bersangkut-paut dengan peran melayani penonton menari, ronggeng-ronggeng itu hadir juga pada teater tradisional yaitu Longser, Banjet, Uyeg, dan Ubrug. Di sini selain menari mereka berperan juga sebagai aktor. Karena hadir pada pertunjukan yang membawakan lakon tersebut maka mereka kerap dipanggil sebagai ronggeng longser, ronggeng banjet, ronggeng uyeg, atau ronggeng ubrug. Sedang mereka yang hadir pada pertunjukan Wayang

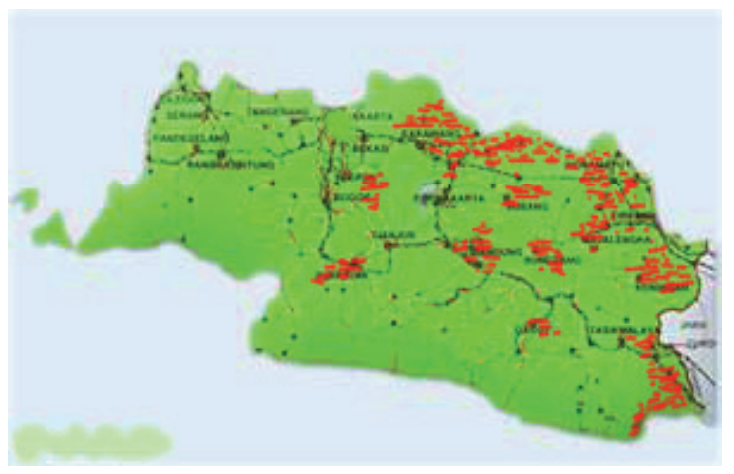

Gambar 4

Peta Persebaran Seni Ronggeng di Jawa Barat

Golek di mana perannya terbatas sebagai penghidang lagu kerap dipanggil sebagai ronggeng wayang.

Gejala-gejala seperti itulah rupa-rupanya yang menyebabkan mengapa kata ronggeng acapkali diplesetkan dengan menggunakan metode kirata basa (metafora). Di wilayah Priangan kata ronggeng akronim dari dirongrong ditonggengtonggeng, yang secara sosial maksudnya sama dengan nyerong bari nyenggeng dan rongketunggengyangdiucapkan di wilayahwilayah kultur Cirebon dan Banyumas. Kemudian dapat diduga pula bahwa ejaan 'rong' 'geng' (Raffles, 1837:342) merupakan pelafalan dari wronk-gank alias 'kelompok yang buruk'; identik dengan biang keributan sekaligus wahana dari 'mim-pitu', tujuh hal yang mesti dijauhi baik menurut norma agama maupun norma sosial. Akhirnya, seorang perempuan yang suatu saat berperilaku tidak pantas terpaksa harus menerima sumpah serapah: "...si ronggeng siah, si dayang, si ungkluk..."

Di lain fihak di wilayah kultur Cirebon terdapat kesenian yang menyuguhkan tarian magis yang dibawakan oleh seorang perempuan dan dinamakan Ronggeng Buyung. ${ }^{5}$

Di lain fihak lagi di Cirebon terdapat kesenian Ronggeng Bugis ${ }^{6}$ yang pelaku 


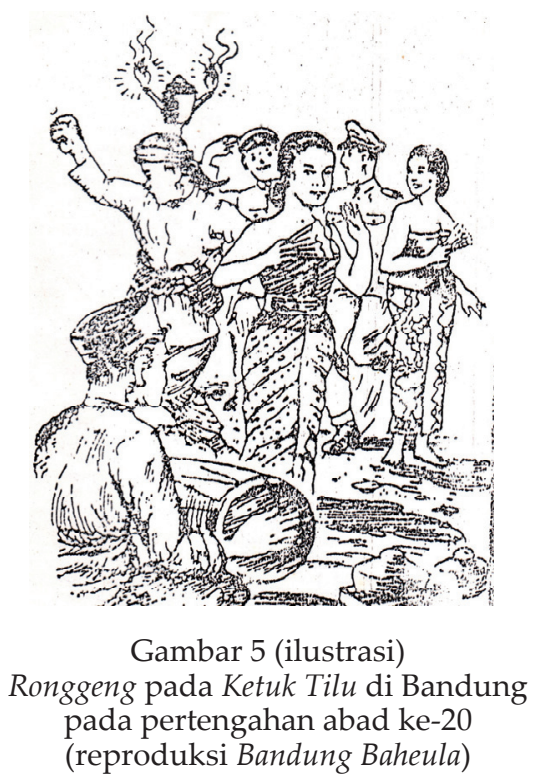

ronggengnya adalah laki-laki yang berdandan perempuan sekaligus menirukan perilaku perempuan. Gejala ini rupa-rupanya yang ditemukan oleh Pigeaud (1938: 268-269) masa lampau yang kemudian menyebutnya sebagai manlijk ronggeng. Pigeaud mengatakan: “...de transvesty-vertoningen van een jongen of man, als vrouw verleed... hij was gekleed met een borksteleed (kemben) en droeg een slendang als een vrouw...hij danste aleen..

Kesenian ini disuguhkan dalam bentuk helaran, para penari hanya melakukan gerak 'kuntul longok' yang sudah pasti bertujuan untuk menimbulkan kelucuan.

\section{Benang Merah Ronggeng Ritual-magis}

Di Kuningan, tepatnya di Ciniru hingga tahun 1980 kerap dilaksanakan upacara Babarit Desa yang diiringi oleh pesta Tayub. Sebelum Tayub dilaksanakan, pada senja hari ronggeng melakukan prosesi yaitu menghadap empat arah mata angin: kulon, wetan, kidul, dan kaler. Angka 4 dan 1 memiliki makna khusus yang ber-

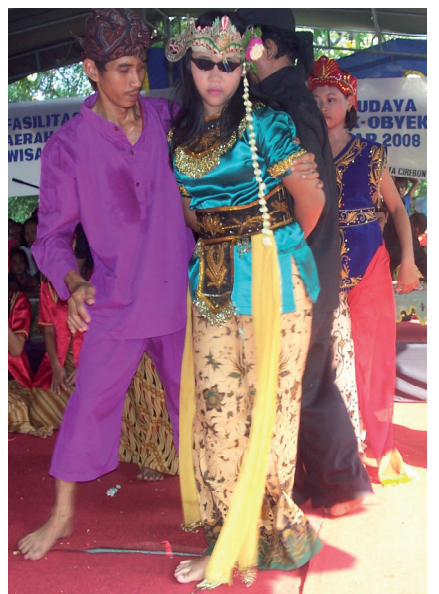

Gambar 6 (foto)

Ronggeng Buyung (Sintren) di Cirebon yang menyuguhkan atraksi magis (foto koleksi Anis Sujana). hubungan dengan waktu kudus (sakral). Angka 4 dianggap sebagai quartenitas (empat sudut=empat bagian=empat arah), merupakan suatu arketip yang hampir universal; ia membentuk dasar logis bagi suatu pemahaman yang lengkap (Nalan, 1994:80). Selesai prosesi dilanjutkan oleh pesta Tayub yang pola pelaksanaannya tidak berbeda dengan pelaksanaan Tayub di luar konteks upacara.

Di Garut diberitakan oleh oleh Hasan Mustafa tentang Bupati Garut yang pada pesta panen mengikut-sertakan sosok ronggeng. Lebih jelas lagi pada acara mengangkut padi ke lumbung dilaksanakan helaran (arak-arakan) di mana sosok ronggeng ditempatkan di atas sebuah jampana dan ditandu secara bersama-sama. Keadaan demikian mengindikasikan bagaimana ronggeng menempati kedudukan istimewa.

Di Ciamis selatan sebagai habitat kesenian Ronggeng Gunung, ronggeng kerap tampil pada kegiatan-kegiatan ritus dalam siklus pertanian yaitu ngawuluku, tandur, dan panen. Pada mimiti ngawuluku ronggeng menari dan berdendang di saung 


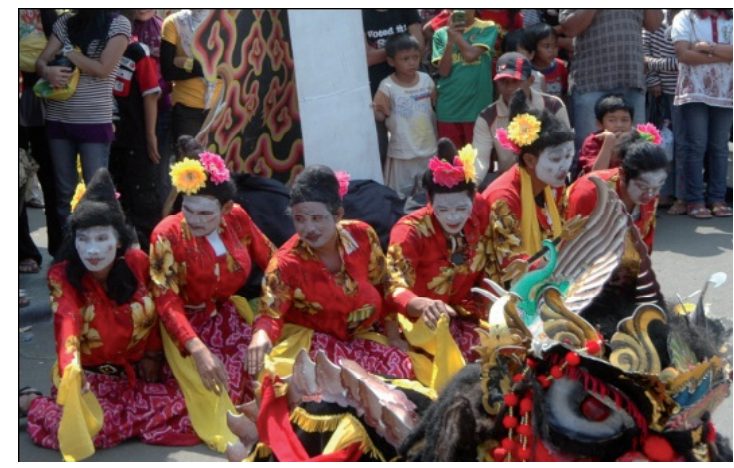

Gambar 7 (foto)

Ronggeng Bugis di Cirebon (foto koleksi Anis Sujana)

atau pisaungeun pemilik sawah. Pada mimiti tandur pelaksanaannya sama dengan pada mimiti ngawuluku, namun demikian pada acara ini ronggeng berkenan menanam indung pare yang kemudian diikuti oleh warga. Apabila kemarau panjang sehingga berakibat tertundanya waktu bertani menurut perhitungan musim, maka terlebih dahulu diadakan upacara ngamandian ucing. Diberitakan pada malam hari ronggeng melakukan prosesi ngais seekor kucing berjalan dan berdendang melewati perkampungan. Lama kelamaan prosesi itu membentuk helaran karena dari setiap tempat yang dilalui beberapa warga secara spontan mengirinya. Di tempattempat yang menjadi sumber air seperti perigi dan sungai, kucing itu dimandikan. ${ }^{7}$ Selama itu juga berlangsung acara siraman yakni segenap yang hadir membasuh diri dan saling menyiram dalam suasana sukacita. Pada upacara mapag sri, pada siang hari seorang ronggeng melakukan prosesi yaitu mengais pare indung yang diikat bersama daun sulingkar serta dibungkus boeh, berjalan sambil berdendang menuju rumah diiringi tetabuhan. Di belakangnya adalah rombongan lelaki yang memikul padi menggunakan rengkong. Sampai di rumah padi dimasukkan ke dalam leuit. Menurut keterangan ronggeng

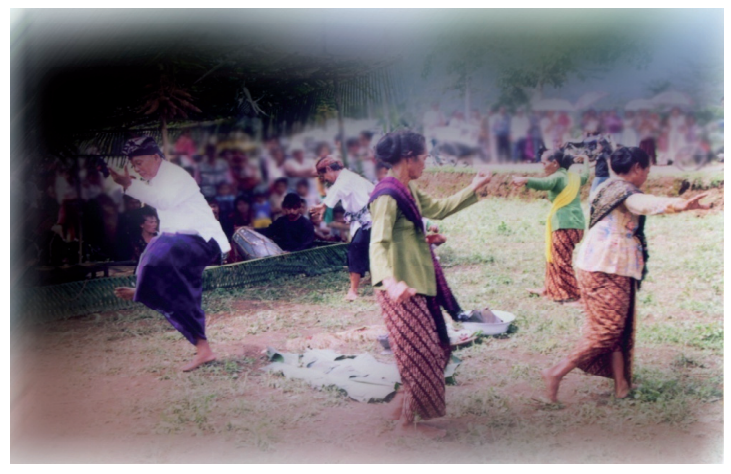

Gambar 8 (foto)

Ronggeng pada Ketuk Tilu 'minta hujan' Di Kecamatan Tanjung Siang Kabupaten Subang (foto dokumentasi Mas Nanu Muda)

yang diminta untuk manggung kedatangannya harus dijemput. Utusan diharuskan membawa kendi berisi air, dan ketuk. Kendi yang berisi air adalah persediaan minum ronggeng di jalan, sedang ketuk yang sewaktu-waktu ditabuh sebagai pertanda ronggeng yang bersangkutan sudah ada yang nyangcang. ${ }^{8}$ Sumber lain menyebutkan, pada suatu masa imbalan yang diberikan kepada ronggeng adalah berupa barang, umpamanya kain, kebaya, selendang, dan payung. Hal seperti ini lazim disebut nimpahan.

Di Paneungteung (sebuah dusun di desa Cihanjuang Kecamatan Lembang Kabupaten Bandung), ${ }^{9}$ hingga sekarang masih berlangsung tradisi 'minta air' lewat mata air Ciwangun. Menjelang selamatan disediakan sesajen yang diletakkan di dua tempat yaitu di panggung dan di paniisan. ${ }^{10}$ Menjelang pertunjukan seorang sesepuh memotong seekor ayam hitam, darahnya dioleskan kepada segenap kru Ketuk Tilu sebagai panyinglar. Selanjutnya adalah tawasul yang dalam istilah lain ngiriman karuhun. Tahap selanjutnya adalah tatalu yang dilanjutkan oleh Lagu Kidung dan Kembang Gadung. Bersamaan dengan melantunnya lagu itu ronggeng muncul berjalan berputar kemudian duduk beshap menghadap penonton. Babak selanjutnya adalah 
jujungkungan yang dilanjutkan oleh wawayangan. Selesai tahap ini ronggeng kembali ke tempat semula yakni bergabung bersama panjak. Sebelum kegiatan tari menari ditampilkan lagu Gawil. Lagu yang tanpa tarian ini khusus dipersembahkan kepada Eyang Madasim dan Eyang Surya yang konon sangat menyukai lagu ini, selanjutnya adalah acara tari menari, tunggal maupun layan, maupun berpasangan hingga menari bersama. Setiap selesai babak itu selalu diakhiri oleh oray-orayan penari pria yaitu menari beriringan membentuk angka delapan. Adapun gerak-geraknya berupa mincid dan loncatan kecil, sedang posisi tangan lebar seperti sikap dalam permainan silat. Hal berkenaan dengan lagu-lagunya pada dasarnya sama dengan penjajian Ketuk Tilu pada waktu dan tempat lain.

Di Kecamatan Tanjung Siang Kabupaten Subang ditemukan suguhan Ketuk Tilu yang berkaitan dengan keperluan mendatangkan hujan. Adapun pola pelaksanaannya tidak jauh berbeda dengan umumnya ronggeng ritus, khususnya dengan Ketuk Tilu yang berlangsung di Paneungteung Lembang.

\section{Penutup}

Di Jawa Barat, dalam beberapa kasus ronggeng memiliki fungsi dan bentuk yang sama dengan ronggeng-ronggeng di tempat lain di nusantara. Di satu sisi mereka adalah 'penghibur' dengan penilaian yang cenderung negatif, dan di sisi lain lain sebaliknya sebagai 'penghubung' dunia nyata dan dunia makna yang oleh sebab itu memiliki kedudukan terhormat. Bersangkut-paut dengan ronggeng ritus sekaligus hiburan ini tampak ronggeng memiliki posisi ambigu.
Khususnya dalam hiburan, ronggeng memiliki keaneka-ragaman dalam bentuk dan gaya penampilannya yaitu: 1) sebagai penyuguh tari sekaligus partner penonton dalam tari pergaulan; 2 ) sebagai penyuguh tari sekaligus aktor dalam teater tradisional; 3) sebagai penyuguh tari dan nyanyi 'sendiri'; 4) sebagai penghidang lagu (sinden) dalam Wayang Golek; 5) sebagai penyuguh tari dalam pertunjukan magis, dan 6) sebagai penyuguh tari dalam pertunjukan helaran.

Tidak diketahui secara pasti sejak kapan seni ronggeng yang sakral itu secara perlahan berkurang kadar ritusnya dan mulai menjurus ke arah profan. Dalam kaitan ini boleh kita mengira-ngira: waktunya 'bersamaan' yaitu pada saat upacara usai, maka dilanjutkan oleh hiburan. Teknik dan bentuk gerak serta musiknya mungkin mirip, namun hanya sebagian saja yang masih merujuk kepada simbol-simbol ritualnya. Ini mengandung arti bahwa ronggeng sudah beralih ke dunia 'nyata', semua unsur gerak dan bunyi di sana sudah menjurus ke arah profan. Monotonitas tidak lagi untuk mengundang trance, gerak erotik tidak lagi untuk mendatangkan magi, pola lantai melingkar tidak lagi difahami sebagai aksis mundi. Reward yang diberikan kepada ronggeng pun tidak lagi dalam bentuk hasil bumi (palawija) melainkan dalam bentuk uang. Fungsi telah berubah, maka bentuk pun mengikutinya. Seni ronggeng kini diabdikan untuk kesenangan, kepuasan, hiburan pelepas lelah. Seni ronggeng lambat-laun mulai tercerabut, berlainan arah dan menyimpang dari tujuan upacara, ia kemudian berdiri sendiri dan bisa berada di luar konteks upacara.

Perubahan dan pergeseran dari konteks upacara ke konteks 'hiburan murni' 
bagaimanapun tidak lepas dari kebutuhan ekonomi. Jika pada musim tanam dan musim panen (dalam konteks budaya agraris), ronggeng mendapat upah palawija, maka pada musim paceklik tidak ada jaminan ke arah itu. Fungsi berubah, maka bentuk pun mengikutinya. Seni ronggeng kini diabdikan untuk kesenangan, kepuasan, hiburan pelepas lelah. Seni ronggeng lambat-laun mulai tercerabut, berlainan arah dan menyimpang dari tujuan upacara, ia kemudian berdiri sendiri dan berada di luar konteks upacara.

Perubahan dan pergeseran ronggeng dari perempuan ke lelaki dalam konteks ronggeng hiburan pun alasan ekonomi akan dapat difahami. Bahwa kegiatan tarimenari di lingkungan rakyat kebanyakan dan dalam tujuan untuk menghibur tampaknya tidak menjadi monopoli kaum perempuan. Atau dalam kata lain pesona penari perempuan memberi daya tarik lebih dibanding lelaki. Pergantian peran oleh laki-laki ketika seni-seni ronggeng itu mulai bergerak ke arah profan yang menyebabkan ruang gerak perempuan menjadi terbatas: penilaian terhadap mereka negatif, tidak terhormat. Atau bisa juga yang menjadi prasarat ronggeng itu tetap harus perempuan, namun bilamana kemudian keperempuan-perempuanan, sekurang-kurangnya berdandan seperti perempuan.

Lepas dari pelbagai macam celaan dan sanjungan, dan lepas pula dari keragaman bentuk dan teknik penampilannya, ronggeng pernah menduduki peranan sentral dalam masyarakat. Adanya situs-situs makam ronggeng, guha ronggeng, dan leuwi ronggeng yang kerap diziarahi menjadi petunjuk ke arah itu. Dan khususnya dalam ranah tari pergaulan, ronggeng telah memberikan konstribusi yang besar pada perkembangan seni-budaya di Jawa Barat. Kehadiran ronggeng telah menjadi sumber inspirasi bagi novelis/penyajak, perupa, dan koreografer untuk penciptaan karyakarya mereka. Tentu dalam penuangannya menurut tafsir dan sudut pandang yang berbeda-beda, mulai dari sisi perjalanan hidupnya hingga sisi keindahan gerak tubuh dan wajah elok yang dimilikinya. Dalam hal ini diketahui beberapa karya sastra, seni rupa, dan seni tari yang terinspirasi oleh ronggeng antara lain: Ronggeng Dukuh Paruk, Jante Arkidam, Longser (karya sastra), De Ronggengs, Inlandsche Dansers en Ronggings te Tjibinuangan (seni rupa), dan Ronggeng Pangbarep (seni tari). Selebihnya adalah Jaipongan yang menjadi booming tari tontonan di Jawa Barat yang nyata-nyata salah satu sumbernya adalah seni ronggeng.

\section{Catatan Akhir}

${ }^{1}$ Dari uraian selanjutnya, ronggeng inilah ruparupanya yang mengembangkan Topeng Betawi dan Topeng Banjet sekarang.

${ }^{2}$ Ronggeng Dukuh Paruk adalah novel karya Ahmad Tohari. Seperti yang dinyatakan pengarangnya sendiri, novel itu diambil dari realitas sosial yang ada dalam masyarakatnya (Dukuh Paruk). Tohari (Hellwig, 1990:160) menyatakan bahwa tokoh utama yang menjadi model dalam RDP masih hidup sampai saat ini. Fakta menunjukkan bahwa novel trilogy RDP merupakan karya yang mendapat tanggapan positif dari banyak pemerhati sastra. Hal itu terbukti dari diterjemahkannya ke dalam bahasa Inggris, Perancis, Jerman, dan Jepang. Bahkan sudah dijadikan bahan penulisan skripsi kesarjanaan oleh lebih dari dua puluh mahasiswa (periksa: Suhendi, 2006: 24-25).

${ }^{3}$ Hal dengan erotisme sebagai simbol lambang kesuburan itu seiring dengan linggaisme yang pernah menjadi faham masyarakat Indonesia lama. Suharto (1999: 32-33) menuturkan terdapatnya sebuah prasasti yang dikenal sebagai prasasti Canggal. Isi dalam prasasti ini merupakan peringatan didirikannya sebuah lingga atau phallus sebagai lambang Siwa yang terdapat di atas sebuah bukit di daerah Kunjarakarna oleh Raja Sanjaya. Kemudian di dalam kompleks Candi Prambanan masih terdapat peninggalan lingga yang masih utuh dan berdiri pada landasan atau tumpuan yoni. Bukan tidak mustahil lingga dan yoni itu meru- 
pakan lambang kesuburan mengingat di dalam maknanya terkandung persatuan antara laki-laki dan perempuan sebagaimana orang-orang primitif memakainya untuk menciptakan keseimbangan agar alam juga mampu memberikan hidup pada tumbuh-tumbuhan yang mereka katakan mempunyai nyawa. Dari perspektif lingga-yoni ini suguhan Tari Bedoyo di Keraton Yogyakarta dapat dipandang sebagai simbol penyatuan itu. Raja yang hadir dan 'duduk tegak' dalam suguhan Bedoyo itu dilambangkan sebagai lingga, sedang penari Bedoyo yang jumlahnya berbilang dipandang sebagai yoni. Masih berhubungan dengan kesuburan, pada relief candi digambarkan penari solo wanita yang diiringi oleh dua figur pria berjenggot, gemuk, tanda-tanda ikonografis dari seorang Brahmana dalam seni Jawa-Hindu. Stutterheim (Soedarsono, 2000:143) menduga ada hubungan antara brahmana-brahmana itu dengan pasangan dua petugas yang sampai abad ke-20 memainkan peranan yang tak dapat difahami, dan sedikit jenaka pada upacara-upacara istana tertentu. Di sebuah istana (mereka menggunakan jenggot-jenggot tempelan), mereka membantu para penari dengan teriakan-teriakan dan tepukan-tepukan tangan; di istana yang lain, tugas mereka termasuk pengawasan pada tledhek-pesindhen. Dengan demikian para brahmana di Barabudur mungkin mengombinasikan fungsi para ahli tari dengan pengawasan umum para gadis penari. Dari dua stanza Nagarakrtagama diperoleh keterangan tentang seorang penari wanita dalam tujuh hari perayaan yang diselenggarakan setelah panen untuk menyanjung kebesaran raja dan istananya sebagai pusat dari kemakmuran. Holt menduga brahmana ini adalah buyut-buyut (embah buyut) seperti digambarkan dalam Nagarakrtagama itu. Buyutbuyut ini adalah pelawak yang bersahaja seperti yang mengiringi ronggeng pada masa Raffles. Selanjutnya Holt membandingkan buyut pada relief dan kesusastraan dengan pelawak (vidushaka) dari teater India klasik yang "seorang Brahmana tetapi jelek dan lucu. Juru I Angin menyanyi ketika ia menari, rupanya dengan nada humor yang semuanya mengundang ketawa. Setelah selesai Juru I angin dilimpahi pemberian busana, dan setelah itu diundang pada kehadiran sang raja untuk menyantap minuman keras menemani beberapa orang terkemuka." Pigeaud percaya bahwa peranan dari Juru I Angin mungkin telah resmi diakui sakral; bahwa ia mungkin telah menjelma sebagai seorang dewi setempat yang namanya saja tetap lestari pada foklor Jawa yaitu Ratu Angin-angin. Selagi Angin-Angin berarti angin, ia mungkin lambang dari angin musim barat yang membawa hujan hingga dengan demikian pada dasarnya seorang dewi kesuburan (2000:144)

${ }^{4}$ Kaitan dengan inilah rupa-rupanya yang kemudian memunculkan sebutan pamogoran; yang menunjuk kepada penggemar Ketuk Tilu yang memiliki kebiasaan menginap di rumah ronggeng.

${ }^{5}$ Umum menamakan kesenian tersebut sebagai Sintren yang penyebarannya meliputi pesisir Jawa Tengah, Jawa Barat, hingga Banten.

${ }^{6} \mathrm{Hal}$ berkenaan dengan penamaan Ronggeng Bugis diduga merujuk kepada nama etnik Bugis (Sulawesi) di mana terdapat kesenian Pajogeq (sejenis ronggeng) yang pelakunya waria (periksa: Indonesia Heritage Seri 8 Performing Arts, 1998:87). Hal yang perlu diketahui adalah anggapan umum sekarang yang menyatakan kemunculan Ronggeng Bugis berasal dari kegiatan telik-sandi pasukan Cirebon dalam perlawanan terhadap Pajajaran (periksa: Azis, Abdul, dkk. 1994).

${ }^{7}$ Kucing ditanggapi sebagai binatang yang alergi terhadap air, oleh sebab itu kucing dipandang sebagai tokoh antagonis yang dipertentangkan dengan air.

${ }^{8}$ Ronggeng yang diperlakukan seperti demikian mengingatkan kepada paraji di pedesaan pada masa silam; seseorang ditugasi menjemput paraji malam hari dengan pelengkapan obor manakala seorang perempuan akan melaksanakan persalinan.

${ }^{9}$ Secara geografis Paneungeung merupakan area perbukitan yang oleh karenanya secara umum mata pencaharian penduduk adalah bercocok tanam dan beternak. Kebiasaan lama yang berhubungan dengan kepercayaan menjadi bagian hidup masyarakat. Dengan begitu mereka memiliki kebiasaan menyajikan sesajen, mengubur kepala kerbau yang dimaksudkan sebagai wadal. Diberitakan bahwa tahun 1901 Eyang Madasim yang menjadi sesepuh masyarakat menggagas saluran air sungai untuk pengairan sawah. Saluran itu dibangun secara gotong-royong melibatkan semua warga masyarakat. Ketika saluran itu selesai kemudian diberi nama Ciwangun, artinya saluran yang dibangun. Sesuai nadzar sebelum pembangunan itu dilaksanakan diadakan syukuran yang dimeriahkan oleh Ketuk Tilu. Ketuk Tilu di Paneungteung akhirnya menjadi tradisi setahun sekali, terutama ketika menghadapi kemarau panjang. Keadaan itu berlangsung hingga tahun 1950-an. Namun begtu pernah mengalami stagnasi karena adanya gangguan keamanan. Kegiatan dimulai lagi sejak tahun 1950-an sampai sekarang. Dohot Tarmana pimpinan Manggung Sari mengaku sudah dua belas kali mentas Ketuk Tilu di Paneungteung Lembang.

${ }^{10}$ Sesajen di panggung ditujukan untuk arwah leluhur nu ngageugeuh panggung, sedang sesajen di paniisan ditujukan untuk arwah leluhur nu ngageugeuh mata air Ciwangun.

\section{DAFTAR PUSTAKA}

Abdul Azis, dkk.

1994 "Tari Ronggeng Bugis di Kabupaten Cirebon". Laporan Penelitian Akademi Seni Tari Indonesia (ASTI) Bandung.

\section{Ahmad Tohari}

1970 Ronggeng Dukuh Paruk: Trilogi. Jakarta: PT Gramedia. 
Ajip Rosidi, et.al.

2000 Ensiklopedi Sunda: Alam, Manusia, dan Budaya: Termasuk Budaya Cirebon dan Betawi. Jakarta: Pustaka Jaya.

\section{Arthur S. Nalan}

1994 "Sanghyang Raja Uyeg: Suatu Kajian Tentang Kedudukan, Peranan, dan Fungsi Tokoh dalam teater Uyeg Sukabumi Jawa Barat". Tesis S-2 Program Studi Kajian Pertunjukan Jurusan Ilmu-ilmu Humaniora Fakultas Pasca Sarjana Universitas Gadjah Mada Yogyakarta.

\section{Ben Suharto}

1999 Tayub, Pertunjukan \& Ritus Kesuburan. Bandung: Masyarakat Seni Pertunjukan Indonesia (MSPI).

Brandon, James R.

1967 Theatre in Southeast Asia. Terj. RM. Soedasono. Bandung: P4ST UPI.

Edi Sedyawati

1984 Tari, Tinjauan Dari Berbagai Segi. Jakarta: PT Dunia Pustaka Jaya.

Hardouin, E.

1855 Java: Neelen Uit Het Leven, Karakterschetsen en Kleederdragten van Java's Bewoners's. Gravenhage: K Fuhri.

Holt, Claire

1967 Art in Indonesia, Continuities and Change. Terj. RM Soedarsono. Bandung: MSPI.

I Made Bandem

1996 Evolusi Tari Bali. Yogyakarta: Kanisius.
Jakob Sumardjo

2004 "Pendekatan Budaya Atas Seni Rupa Tradisi Budaya Etnik Indonesia" dalam "Kumpulan Tulisan Metodologi Penelitian Seni". Banung: Departemen Seni Murni Fakultas Seni Rupa dan Desain Institut teknologi Bandung.

Kleden, Ninuk. et.al.

2000 Pendefinisian Kembali Tradisi dan IIdentitas Etnik. Jakarta: Puslitbang Kemasyarakatan dan Kebudayaan Lembaga Ilmu Pengetahuan Indonesia (PMB-LIPI).

Lembaga Basa \& Sastra Sunda

1994 Kamus Umum Basa Sunda. Banung: Tarate.

Lombard, Denys

1996 Nusa Jawa: Silang Budaya, Jaringan Asia 2. Jakarta: PT Gramedia Pusta ka Utama.

L. Mardiwarsito

1990 Kamus Jawa Kuna-Indonesia. EndeFlores: Nusa Indah.

Pigeaud, Th.

1938 Javaanse Volksvertoningen, Bijdrage tot de Bescrijuing van Land en Volk. Batavia: Volkslectuur.

Raffles, Thomas Stamford

1937 The History of Java. Kualalumpur: Oxford University Press.

Ririn Sri Wulandari

2000 "Shindenan Ibu Kunes dalam Calung Banyumasan". Skripsi S-1 Program Studi Seni Karawitan Ju- 
rusan Karawitan Sekolah Tinggi Seni Indonesia (STSI) Bandung.

R.I. Maman Surjaatmadja

1980 Tari Topeng Cirebon dan Peranannya di Masyarakat. Bandung: STSI Press

R.P. Capt. Suyono

2005 Seks Dan Kekerasan Pada Zaman Kolonial, Penelusuran Kepustakaan Sejarah. Jakarta: PT Gramedia Widiasarana Indonesia.

Suhendi

2004 Srinthil. Media Perempuan Multikultural. No. 6 Th. 2004, Jakarta.
S. Dloyana Kusumah

1981/ Ronggeng Gunung: Sebuah Keseni-

1982 an Rakyat di Kabupaten Ciamis Jawa Barat. Jakarta: Proyek Media Kebudayaan Jakarta Dirjen Kebudayaan Depdikbud.

Yayasan Dana Bakti

1998 Indonesia Heritage Seri 8 Performing Arts. Jakarta: Yayasan Dana Bakti.

Zoetmulder, P.J.

1982 Old Javanese-English Dictionary. S'Gravenhage Martinus Nijhoff. 